\title{
Revision of the Hawaiian Stylasteridae (Cnidaria: Hydrozoa: Athecata) ${ }^{1}$
}

\author{
Stephen D. Cairns ${ }^{2}$
}

\begin{abstract}
Four species of stylasterids are described from the Northwestern Hawaiian Islands (Kure to Kaua'i) at depths of 293-583 m, including three new species: Distichopora asulcata, Stylaster griggi, and S. infundibuliferus. In addition, specimens of Distichopora anceps were observed and collected, showing it to be the most common macroinvertebrate on the northwestern slope of Laysan Island but not known from any other Hawaiian locality. Its description was amended to include branching colonies with up to 20 lobes; a suggested ontogeny of these growth forms is illustrated. Also, unique sexually dimorphic features of both male and female ampullae of $D$. anceps are described.
\end{abstract}

Although there had been several undocumented reports of stylasterid corals from the Hawaiian Islands before 1978, Boschma $(1959: 134,1964: 186)$ surmised that they were all based on inaccurate reports or concerned specimens that were bought in Hawai'i but probably transported from another island group, such as the Marquesas, to be sold to tourists in $\mathrm{O}^{\prime}$ ahu. Boschma (1959:134) finally concluded: "Taking these data into consideration it seems fairly conclusive that Stylasterine corals do not occur in the Hawaiian Islands." However, the first and, until now, only documented record of a stylasterid from the Hawaiian Islands was the report of four specimens of Distichopora anceps Cairns, 1978, from 360 to $402 \mathrm{~m}$ (corrected depth) off Laysan. In this report three additional species are reported for the Northwestern Hawaiian Islands, bringing the total for Hawai'i to four species, but the paucity of stylasterids from this archipelago is still surprising for a region of this size and characteristics. Cairns (1992) mapped the worldwide distribution of all reported stylasterids, showing that they occur predominantly in insular

${ }^{1}$ Manuscript accepted 8 August 2004.

2 Department of Invertebrate Zoology, MRC 163, National Museum of Natural History, Smithsonian Institution, P.O. Box 27012, Washington, D.C. 20013-7012 (e-mail: cairns.stephen@nmnh.si.edu).

Pacific Science (2005), vol. 59, no. 3:439-451

(C) 2005 by University of Hawai'i Press

All rights reserved environments, preferably living on seamounts or on the slopes of volcanic islands having a landmass less than $36,000 \mathrm{~km}^{2}$. Such oceanic regions usually have a constant salinity, a low suspended sediment load, hard substrate, and low nutrient levels, all factors that seem to favor stylasterids and all factors that are common throughout the Hawaiian Islands. The largest of the Hawaiian Islands, Hawai' $i$, is about $10,400 \mathrm{~km}^{2}$ in area. Thus, one might expect stylasterids to occur throughout the archipelago, and when the deepwater environment is better known I expect that many more species will be reported.

\section{MATERIALS AND METHODS}

Most of the specimens reported herein and the impetus for this study resulted from an oceanographic expedition to the Northwestern Hawaiian Islands during October and November 2003, in which I participated. The support vessel, the R/V Ka'imikai-oKanaloa of the Hawaiian Underseas Research Laboratory, was the base for dives of the three-person submersible Pisces $V$, rated to $2,000 \mathrm{~m}$, and the $R C V-150$, a tethered remotely operated vehicle rated to $914 \mathrm{~m}$. Specimens were also obtained from a series of cruises of the R/V Townsend Cromwell during 1970-1972, called the SANGO expeditions. Several specimens were also obtained from the private collections of Beatrice and Tom Burch.

The scanning electron photomicrographs were made by me on an AMRAY 1810 scanning electron microscope. Most specimens 
are deposited at the National Museum of Natural History, Smithsonian Institution; some duplicates are also deposited at the Bishop Museum.

The following abbreviations are used in the text: BPBM, Bernice Pauahi Bishop Museum, Honolulu, Hawai' $\mathrm{i} ; \mathrm{H}: \mathrm{W}$, heightto-width ratio of a gastrostyle; $\mathrm{NMNH}, \mathrm{Na}-$ tional Museum of Natural History (formerly USNM), Smithsonian Institution, Washington, D.C.; RCV, a tethered remotely controlled vehicle; SANGO, a series of cruises of the R/V Townsend Cromwell (sango is the Japanese word for coral); USNM, United States National Museum (now the National Museum of Natural History, Smithsonian Institution).

\section{SPECIES ACCOUNT}

Class Hydrozoa Order Filifera

Superfamily Hydractinoidea Bouillon, 1978 Family Stylasteridae Gray, 1847

Distichopora anceps Cairns, 1978 Figures $1 A-H, 2 A-I$

Distichopora (Haplomerismos) anceps Cairns, 1978:84-86, figs. 1-6; 1983:474-476, fig. $16 A-G, \quad 24 C, \quad 25 F, \quad 28 E$ (histology); 1991:17 (deposition of types).-Cairns and Macintyre, 1992:98 (mineralogy).

Distichopora anceps.-Cairns, Hoeksema, and van der Land, 1999:42 (listed).

material examined. Pisces $V-533 a, 25^{\circ}$ $52.041^{\prime} \mathrm{N}, 171^{\circ} 57.848^{\prime} \mathrm{W}, 501-577 \mathrm{~m}, 19$ October 2003, 19 female colonies or fragments, 16 male colonies or fragments, SEM stubs 1101-1103, USNM 1021949, 1 male and 1 female colony, врвм D1071; Pisces $V$-533b, $25^{\circ} 52.046^{\prime} \mathrm{N}, 171^{\circ} 57.839^{\prime} \mathrm{W}, 481-485 \mathrm{~m}$, 19 October 2003, 4 female colonies, 2 male colonies, 2 gender indet., USNM 1021950; $R C V-150$, dive $250,25^{\circ} 53.90^{\prime} \mathrm{N}, 171^{\circ}$ 55.28' W, 429-495 m, 14 October 2003, observations only (no specimens collected); $R C V-150$, dive 251, 25 $50.53^{\prime} \mathrm{N}, 171^{\circ}$ 58.098' W, 370-403 m, 14 October 2003, observations only (no specimens collected);
$R C V-150$, dive 252, $25^{\circ} 50.49^{\prime} \mathrm{N}, 171^{\circ}$ 57.822' W, 396-397 m, 15 October 2003, observations only (no specimens collected); $R C V-150$, dive $253,25^{\circ} 50.519^{\prime} \mathrm{N}, 171^{\circ}$ 57.668' W, 362-381 m, 15 October 2003, observations only (no specimens collected); $R C V-150$, dive 254, $25^{\circ} 50.470^{\prime} \mathrm{N}, 171^{\circ}$ $57.655^{\prime} \mathrm{W}, 353-388 \mathrm{~m}, 15$ October 2003, 1 gender indet., USNM 1021951.

REMARKs. This uniquely shaped stylasterid was described and redescribed by Cairns (1978, 1983), who included aspects of its morphology and microstructure (SEM), zooid structure, and nematocysts. Cairns and Macintyre (1992) later added observations on its mineralogy, but all of these observations were based on only four type specimens, two of which were dead and somewhat worn when collected. The 46 additional colonies and fragments reported herein allow substantial amplification of the original description of several characters, which are described here.

Originally the species was thought to consist of a stem that supported two flabellate lobes and was thus called anceps, meaning "two headed." The collected specimens and observation of thousands more in situ show that, although the two-headed form is the most common shape of this species, constituting probably more than $90 \%$ of the observed colonies, the species is capable of forming larger colonies (up to $12 \mathrm{~cm}$ in height and a basal diameter of $12.7 \mathrm{~mm}$ [Figure $1 A$ ]) having many more lobes (e.g., more than 20). Figure $2 A-E$ show diagrammatically some of the growth forms observed and a suggested growth transition for colonies having one, two, three, four, and eight lobes. Some colonies exhibit asymmetric growth (Figure $2 F_{-}$ $I)$, which is most likely the result of environmental conditions. All specimens were uniformly white.

As noted in the original description, the flabellar faces and pedicel are covered with closely spaced, parallel ridges. These ridges are $0.3-0.7 \mathrm{~mm}$ apart, a new one intercalating as the flabellum increases in width; the ridges themselves are prominent, up to $0.40 \mathrm{~mm}$ in height, and sharp-edged. Most colonies also bear numerous, small, homogeneously placed 

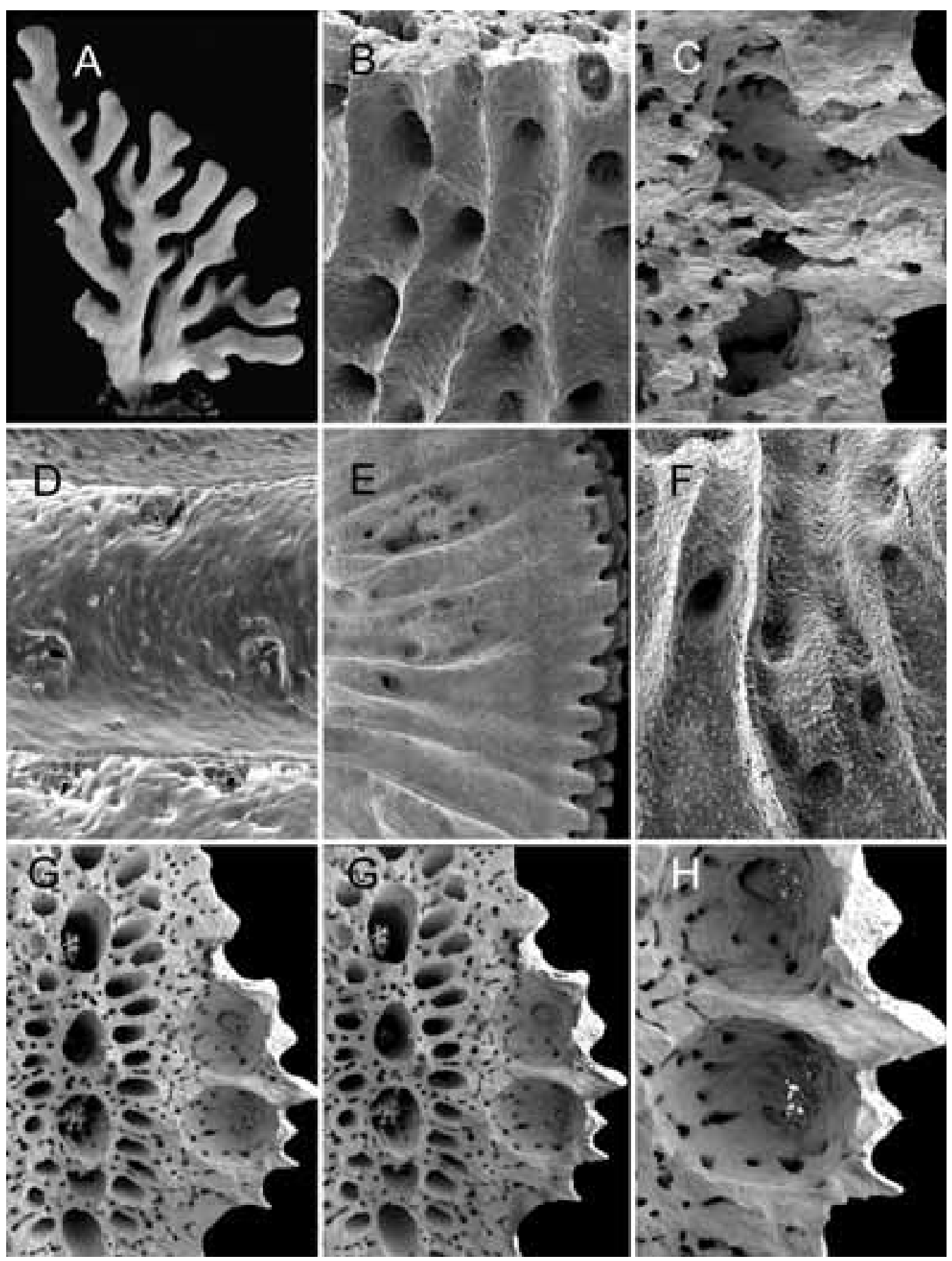

Figure 1. Distichopora anceps from Pisces $V$-533a: $A$, a large colony with multiple lobes, $\times 0.55 ; B$, surface depressions of 15 male ampullae, $\times 17 ; C$, longitudinal fracture through two male ampullae, $\times 38 ; D$, several conical nematopores between two flabellar ridges, $\times 90 ; E-F$, several female ampullae nestled between flabellar ridges, some efferent pores visible, $\times 11, \times 25$, respectively; $G$, stereo pair of longitudinal fracture through two female ampullae showing incipient efferent pore from within ampullae, also cross section of pore row showing dactylopores and gastropores, $\times 17 ; H$, higher magnification of two female ampullae of $G, \times 35$. 

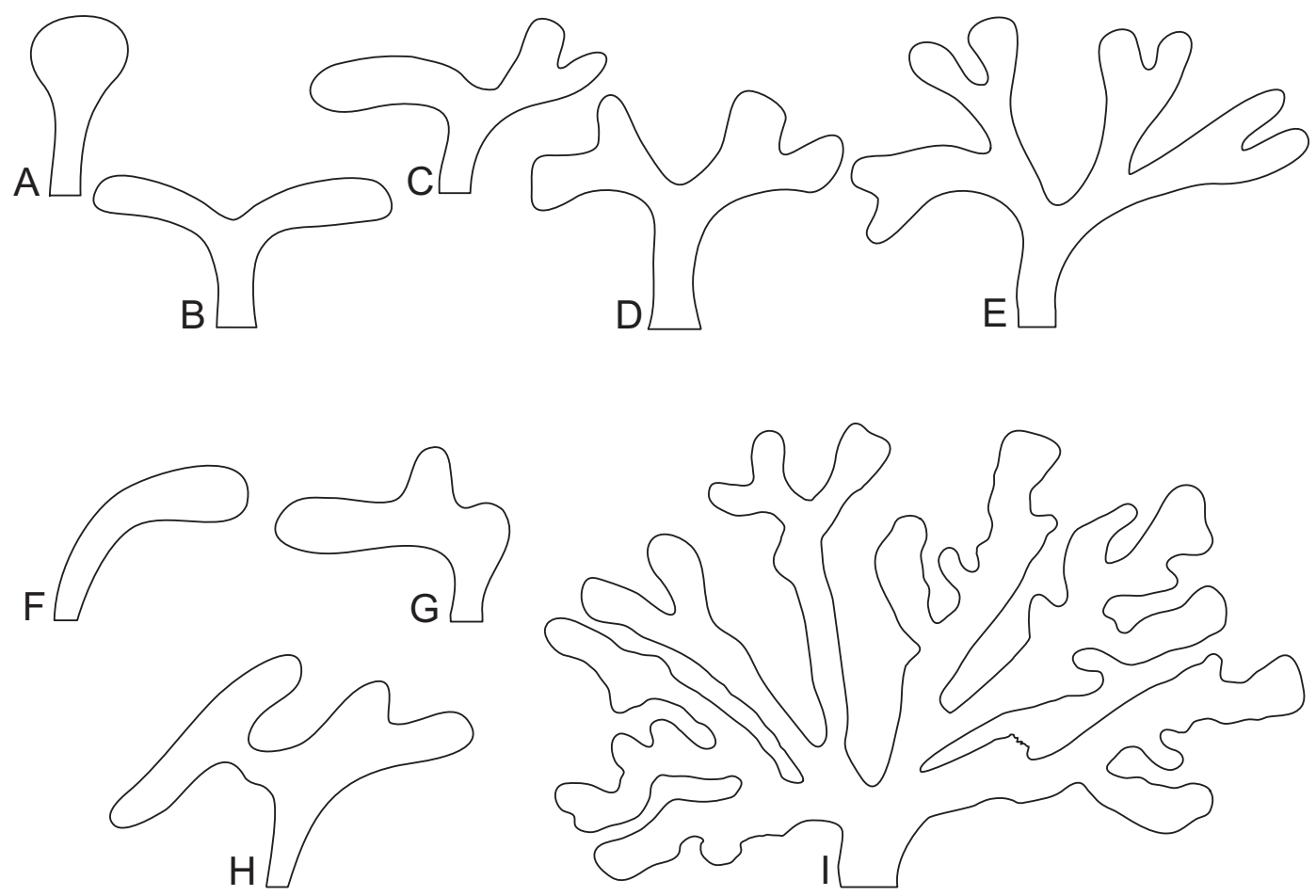

FIgure 2. Diagrams of colonial forms of Distichopora anceps, synthesized from in situ RCV observations: $A-E$, suggested ontogeny from two- to eight-lobed colony form; $F$, an asymmetrical one-lobed colony; $G$, an asymmetrical three-lobed colony; $H$, an asymmetrical four-lobed colony; $I$, a large, well-developed, asymmetrical 20-lobe colony. Diagrams not drawn to scale.

papillae that cover the flabellar faces, each conical mound about $0.10 \mathrm{~mm}$ in diameter and $0.06 \mathrm{~mm}$ in height, each bearing a small slit at its apex, the slit about $25 \mu \mathrm{m}$ in length and $11 \mu \mathrm{m}$ wide. These are presumed to be nematopores (Figure 1D).

Sexual dimorphism and differentiation was unclear in the type specimens, due to their immature size and worn condition, but of the 46 newly collected specimens, 24 were female, 19 male, and three of indeterminate gender, making it possible to fully describe the sexual dimorphism of this species, which is pronounced and unique. The female ampullae are large, superficial, elliptical to teardrop-shaped structures that are nestled between adjacent flabellar ridges. The superficial part is up to $0.9 \mathrm{~mm}$ in greater diameter, but there is an equally sized spherical internal cavity beneath the coenosteal surface, which often contains one yellow egg. Circular efferent pores, measuring $0.10-0.15 \mathrm{~mm}$ in diameter, are often found at both the distal and proximal ends of the ampulla, flush with the coenosteal surface, implying that two eggs/ larvae may develop simultaneously. This is unique in the Stylasteridae. Often a new flabellar ridge will originate on top of a female ampulla and continue to the flabellar edge. The holotype can now be determined to be a female colony. Male ampullae are completely internal and much smaller but also occur linearly between the flabellar ridges. In small colonies there is virtually no surface indication of an ampulla; the internal cavity is about $0.4 \mathrm{~mm}$ in diameter, with some being visible in most branch fractures. As the colony gets larger and the flabellum thicker, a depression or pit develops over the male ampulla that may be up to $0.35 \mathrm{~mm}$ in diameter and of 
equal depth. The base of this pit consists of a thin, porous plate (the efferent pores), which sits on top of the now deeply embedded internal ampullar cavity, which also measures $0.35-0.45 \mathrm{~mm}$ in diameter. Often one can see two to six white spherical gonophores in each male ampullar cavity.

The two-headed form of the colony of this species resembles a maple seed or a wing nut; both common names were used during the expedition to refer to this oddly shaped coral.

ecology and Distribution. Distichopora anceps was observed and collected in great abundance off the northwestern slope of Laysan Island $(360-577 \mathrm{~m})$ in a relatively small region measuring only $10 \mathrm{~km}^{2}$ and which included the original type locality. It is estimated that over 5,000 colonies were observed and photographed via the remotely operated vehicle $(R C V-150)$, with the colonies at times occurring at a density of four to six per square meter. Even though adjacent seamounts and banks were sampled during our cruise, such as Northampton Seamount (12 $\mathrm{km}$ to the west), off Morro Reef, Pioneer Bank, and Raita Bank, the species was never seen again. Furthermore, the Pisces $V$ submersible and RCV pilots on board, who collectively have sampled thousands of deepwater habitats in the Hawaiian Islands, had never seen this distinctive species before. This suggests that $D$. anceps is restricted in distribution to Laysan Island, a remarkably limited distribution even for a family noted for its small geographic ranges and high endemicity (Cairns 1992). It is not known what would cause such a restricted distribution. Other species of Distichopora also have very limited geographic ranges: $D$. vervoorti Cairns \& Hoeksema, 1998 (Nusa Lembongan, a small island off Bali), and D. robusta Lindner, Cairns \& Guzman, 2004 (Isla Jicarita, a small island off Pacific Panama), but those are both shallow-water species and are likely to be found in other localities with greater exploration.

The type specimens of $D$. anceps were stated to have been collected at $658-736 \mathrm{~m}$; however, this was based on the incorrect assumption that the original station data were given in fathoms, not meters. The true depth of the type locality is $360-402 \mathrm{~m}$, which is more consistent with that locality and the recollection from that region.

Off northwestern Laysan $D$. anceps occurs in such abundance that it constitutes the dominant sessile macroinvertebrate in this region, an ecological dominance that is not achieved by any other known stylasterid. Most coralla were firmly attached to a hard substrate, such as lava, and often positioned on the sides or undersides of irregularly shaped boulders. The faces of the flabella were invariably positioned perpendicular to the prevailing current.

\section{Distichopora asulcata Cairns, n. sp.}

Figure $3 A-K$

TYPE MATERIAL. Holotype (USNM 1021955): 1 male colony (now in two pieces), Pisces $V-517,5-15,28^{\circ} 50.50^{\prime} \mathrm{N}, 178^{\circ} 53.881$ W ("Bank 10," about $72 \mathrm{~km}$ northwest of Kure Atoll), $293 \mathrm{~m}, 13.6^{\circ} \mathrm{C}, 29$ October 2003. Paratypes (USNm 1021956): 2 female and 1 male colonies, SEM stubs 1106, 11091110 , Pisces $V-517,5-3$, and $5-4,28^{\circ} 50.30^{\prime} \mathrm{N}$, $178^{\circ} 53.057^{\prime} W$ (“Bank 10”), 342-377 m, 29 October 2003.

DESCRIPTION. Colonies uniplanar and small, the largest specimen (the holotype) $25.8 \mathrm{~mm}$ in height and $23.3 \mathrm{~mm}$ in width but was a part of a larger colony. Branching sparse, the terminal branches strongly flattened, a branch tip being up to $4 \mathrm{~mm}$ in width and only $2 \mathrm{~mm}$ in thickness. Coenosteum white and reticulate-granular in texture; however, coenosteal strips poorly defined, measuring about $0.1 \mathrm{~mm}$ in width. Coenosteal strips covered with small conical mounds about $8 \mu \mathrm{m}$ in basal diameter and up to 10 $\mu \mathrm{m}$ in height or short meandering ridges (Figure $3 G$ ) up to $50 \mu \mathrm{m}$ in length, probably the result of several linked mounds.

Pore rows well defined, $0.70-1.0 \mathrm{~mm}$ in width, and restricted to lateral edges of all branches. Gastropores linearly arranged, ca. 3.5 per millimeter, circular, $0.08-0.17 \mathrm{~mm}$ in diameter, and flush with the coenosteum; no sulcus present, with the coenosteum surrounding the gastropores at the same level and continuous with that of branch faces. 

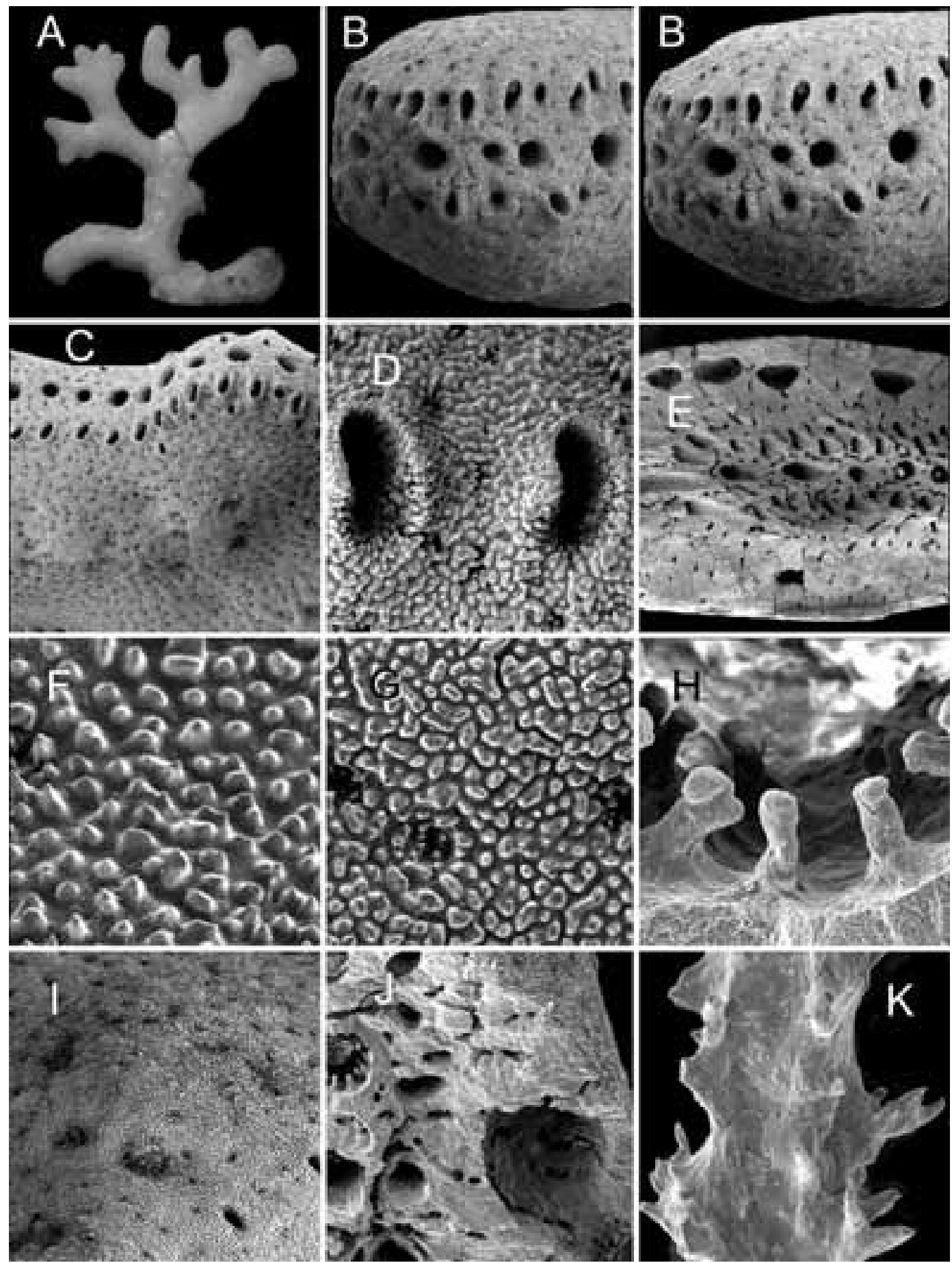

Figure 3. Distichopora asulcata ( $A$, holotype; $B-K$, paratypes from Pisces $V-517,5-3)$ : $A$, holotype, $\times 1.67 ; B$, stereo pair of branch tip showing asulcate pore row, $\times 29$; $C$, pore row and several superficial female ampullae, $\times 15 ; D$, two dactylopore spines, $\times 120 ; E$, cross section of branch showing five internal male ampullae and pore row, $\times 17 ; F-G$, coenosteal texture, $\times 307, \times 195$, respectively; $H$, elements of ring palisade, $\times 335$; I, superficial female ampulla with efferent pore, $\times 34 ; \mathcal{F}$, branch cross section showing internal female ampullar cavity and ring palisade, $\times 48 ; K$, section of a gastrostyle, $\times 460$. 
Gastropore tubes long and curved, paralleling branch axis. A diffuse ring palisade is present within the gastropore tube, the elements cylindrical and blunt-tipped, up to 25-45 $\mu \mathrm{m}$ in height and $18 \mu \mathrm{m}$ in diameter. Gastrostyles needle-shaped, about $60 \mu \mathrm{m}$ in diameter, some of which are at least $1.6 \mathrm{~mm}$ in length $(\mathrm{H}: \mathrm{W}=28+)$, lacking tabulae. Gastrostyles not ridged but bear slender sharp spines up to $30 \mu \mathrm{m}$ in length and $5 \mu \mathrm{m}$ in diameter. Dactylopores arranged on both sides of gastropore row but invariably more common on one side than the other (e.g., 4.7 dactylopores per millimeter on one side versus 2.1 on the opposite side). Dactylopore spines teardropshaped, about $0.15 \mathrm{~mm}$ in length, $0.11 \mathrm{~mm}$ in width, and up to $55 \mu \mathrm{m}$ tall on their outer edges. Dactylostyles absent.

Female ampullae low superficial mounds clustered on both branch faces, $0.5-0.7 \mathrm{~mm}$ in external diameter, most of the ampullar cavity residing below coenosteal surface. Efferent pores circular and $0.14-0.16 \mathrm{~mm}$ in diameter, located at lower edge of superficial ampullar surface. Female ampullae sometimes covered with radiating ridges, giving them a stellate appearance from above. Male ampullae also primarily internal, with only a small superficial mound about $0.5 \mathrm{~mm}$ in diameter and a larger cavity beneath coenosteal surface. Male ampullae also clustered or staggered on both branch faces.

comparisons. Of the 28 species of Distichopora (most listed by Cairns et al. 1999), only eight occur in deep water in the IndoPacific region: D. profunda Hickson \& England, 1909 (Chagos Archipelago, 219-274 $\mathrm{m}$ ); D. providentiae (Hickson \& England, 1909) (Indian Ocean, $228 \mathrm{~m}$ ); D. borealis Fisher, 1938 (Japan and Aleutian Islands, 110-435 m); D. serpens Broch, 1942 (Philippines, 91-183 m); D. anceps Cairns, 1978 (Hawaici, 360-577 m); D. laevigranulosa Cairns, 1986 (Galápagos, 166-806 m); D. dispar Cairns, 1991 (New Zealand, 465-741 m); and D. asulcata, n. sp. Distichopora asulcata is unique in lacking a sulcate pore row and, in general, having the smallest-scale structures (e.g., gastropore and dactylopore diameter, pore row width, coenosteal granule size) of any species. It is most similar to D. serpens, especially in colony shape, color, and coenosteum but differs from that species in lacking a pore row sulcus and in having smaller gastroand dactylopores, smaller female ampullae, and smaller coenosteal granules.

Distribution. Known only from one station northwest of Kure Atoll, extreme Northwestern Hawaiian Islands (see Type Material), 293-377 m.

etymology. The species name asulcata (Latin: $a$, meaning without + sulcatus, sulcus or groove) refers to the asulcate condition of the pore rows.

\section{Stylaster griggi Cairns, n. sp.}

Figure $4 A-7$

TYPE MATERIAL (all preserved dry). Holotype (UsNm 76743): 1 female colony, SANGO 13-15, 24 00.0' N, $166^{\circ} 40.2^{\prime} \mathrm{W}$ (Brooks Banks), 216-330 m, 26 August 1971. Paratypes: usNm 76741, 1 female and 1 male colony, 3 indet. colonies, SANGO 2-6, $22^{\circ}$ $03^{\prime} 50^{\prime \prime} \mathrm{N}, 160^{\circ} 06^{\prime} 18^{\prime \prime}$ (Kaulakahi Channel between Ni'ihau and Kaua'i), 390-436 m, 24 June 1970; usNm 76742, 6 female colonies, 1 indet., SEM stub 1111, and врвм D1072, 1 female colony, SANGO 13-1, $23^{\circ} 57^{\prime} \mathrm{N}$, $166^{\circ} 40.5^{\prime} \mathrm{W}$ (Brooks Banks), 399-412 m, 23 August 1971; UsNm 76336, 4 female colonies, 1 indet., SANGO $13-4,24^{\circ} 00^{\prime} \mathrm{N}, 166^{\circ}$ 42' W (Brooks Banks), 271-346 m, 26 August 1971; USNM 76736, 1 female and 6 indet. colonies, SANGO $13-13,23^{\circ} 57^{\prime} \mathrm{N}, 166^{\circ} 41^{\prime}$ W (Brooks Banks), 244-322 m, 26 August 1971; UsNm 76744, 1 male colony, SEM stubs 1104-1105, SANGO $16-3,21^{\circ} 57^{\prime} \mathrm{N}, 159^{\circ}$ $44^{\prime}$ W (Kaulakahi Channel southwest of Kaua'i), 295-432 m, 8 March 1972; UsNm 76740,1 indet. colony, SANGO 16-8, $22^{\circ}$ $02^{\prime} \mathrm{N}, 159^{\circ} 50^{\prime} \mathrm{W}$ (Kaulakahi Channel southwest of Kaua'i), 391-421 m, 9 March 1972; usnm 76738, 1 female branch, Burch station $76057 \mathrm{HA}, 21^{\circ} 52^{\prime} 30^{\prime \prime} \mathrm{N}, 159^{\circ} 36^{\prime}$ $30^{\prime \prime}$ (Kaulakahi Channel southwest of Kaua' $\mathrm{i}$ ), 383 m, 6 August 1976; usnm 76739, 1 indet. fragment, Burch station 76057HA, 21 $56^{\prime}$ $\mathrm{N}, 159^{\circ} 18^{\prime} 42^{\prime \prime} \mathrm{W}$ (Kaua'i Channel southeast of Kaua'i), 583 m, 8 August 1976; UsNm 76737,3 female branches, Burch station $76059 \mathrm{HA}, 21^{\circ} 56^{\prime} \mathrm{N}, 159^{\circ} 18^{\prime} 42^{\prime \prime} \mathrm{W}$ (Kaua'i 

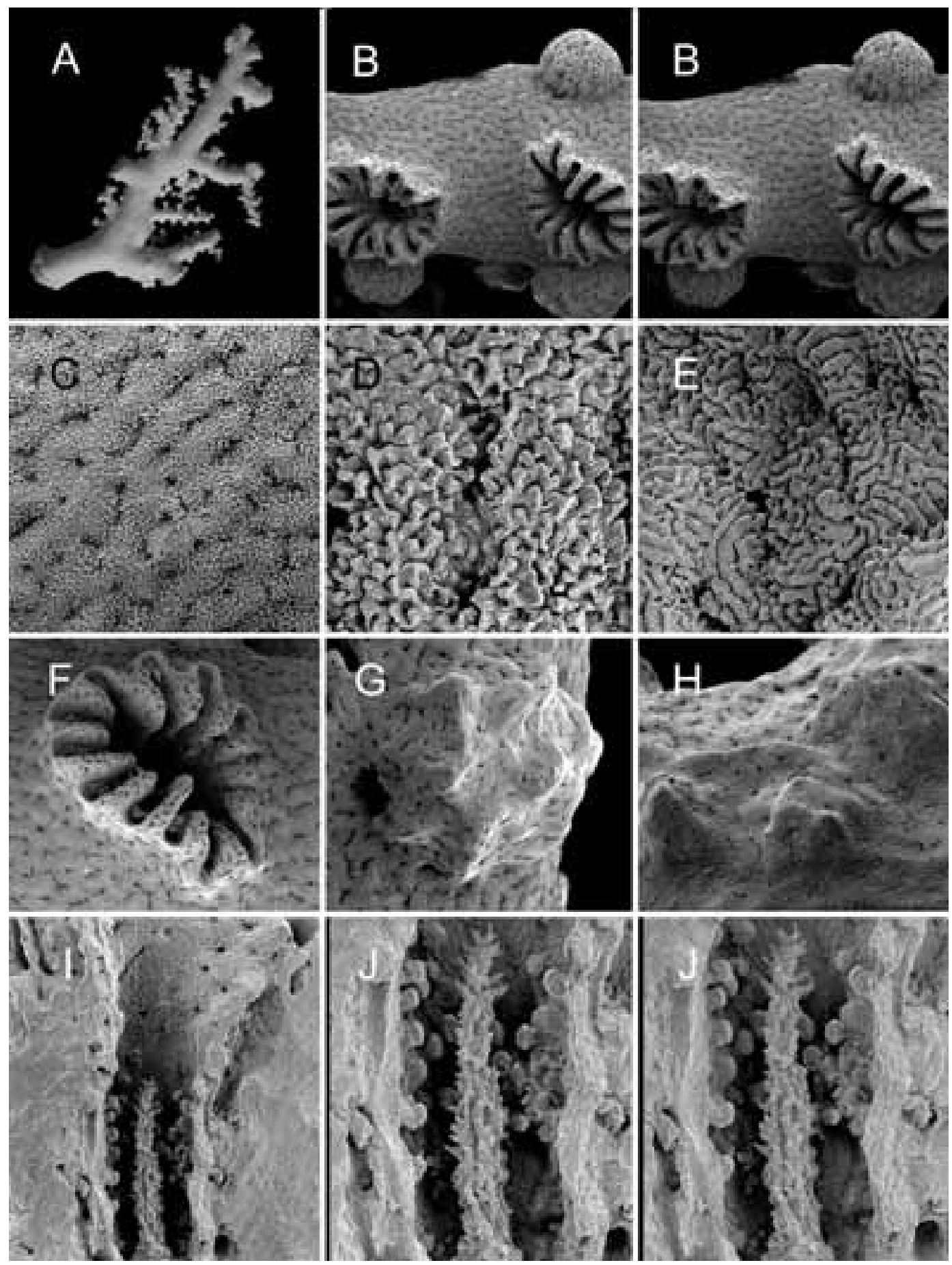

Figure 4. Stylaster griggi ( $A$, holotype; $B, F, I-7$, paratype, usnm 76742; $C-E, G-H$, paratype, usNm 76744$): A$, holotype, $\times 1.1 ; B$, stereo view of two cyclosystems and three superficial female ampullae, $\times 20 ; C-E$, linear-imbricate coenosteal texture, $\times 75, \times 275, \times 150$, respectively; $F$, a cyclosystem with 13 dactylopores, $\times 37$; $G$, a female ampulla with a ruptured efferent pore, $\times 40 ; H$, three superficial male ampullae, $\times 40 ; I$, longitudinal section of a gastropore tube containing an intact gastrostyle and ring palisade, $\times 63 ; \mathcal{F}$, stereo pair of gastrostyle of $I, \times 115$. 
Channel southeast of Kaua'i), 470 m, 8 August 1976.

Description. Colonies uniplanar, moderately branched, and relatively small, the largest corallum (the holotype) $43.7 \mathrm{~mm}$ in height, $30 \mathrm{~mm}$ in width, and $5 \mathrm{~mm}$ in basal branch diameter. Branching sympodial, most cyclosystems oriented perpendicular to the opposite branch edges in an alternating arrangement; branch anastomosis rare. Coenosteum chalky white and reticulate- to linearimbricate in texture, the imbricate nature of coenosteum only apparent on living specimens and at branch tips; the surface texture quickly wears to a smooth or granular texture. Coenosteal strips 55-75 $\mu \mathrm{m}$ wide, bordered by narrow (about $11 \mu \mathrm{m}$ wide), discontinuous slits. Platelets composing strips rarely continuous across a strip, each level composed of 2 5 narrow platelets, the distal edges of which are strongly corrugated.

Cyclosystems stand perpendicular to and are alternately arranged on branch edges (Stylaster group C sensu Cairns 1983) and not very exsert. Cyclosystems usually irregular to elongate in shape, the longer axis up to $1.1 \mathrm{~mm}$ in length and aligned with the branch axis, having length-to-width ratios of 1.62.5. Based on 27 cyclosystems, the range of dactylopores per cyclosystem is $9-15$, average $12.03(\sigma=1.63)$, and mode 13 .

Gastropores circular, about $0.2 \mathrm{~mm}$ in diameter. Gastropore tubes cylindrical and straight, about $1 \mathrm{~mm}$ deep, each bearing a well-developed but diffuse ring palisade occupying the middle $1 / 3$ of tube. Elements of ring palisade rounded to mushroom-shaped, about $40 \mu \mathrm{m}$ in diameter. Gastrostyles elongate and slender, occupying lower half of gastropore tube; illustrated gastrostyle 0.41 $\mathrm{mm}$ in height and $0.063 \mathrm{~mm}$ in width $(\mathrm{H}: \mathrm{W}=6.5)$, covered with tall (up to $30 \mu \mathrm{m}$ in height), slender, sharp spines. Dactylotomes uniformly $60 \mu \mathrm{m}$ wide, but pseudosepta more variable in shape and width, ranging from 0.10 to $0.18 \mathrm{~mm}$ in width; a wider adcauline diastema occasionally present. Dactylostyles prominent, consisting of a crowded row of blunt-tipped pillars, each up to $30 \mu \mathrm{m}$ in height and $8 \mu \mathrm{m}$ in diameter.
Female ampullae quite prominent superficial hemispheres up to $0.75 \mathrm{~mm}$ in diameter, often clustering on both branch faces. Female ampullae irregular in surface texture, each having numerous small apices and short ridges; efferent pore lateral, $0.15-0.18 \mathrm{~mm}$ in diameter. Male ampullae also superficial mounds somewhat irregular in shape, up to $0.55 \mathrm{~mm}$ in diameter and covered with small apices, each apex capped with a small (?efferent) pore about $25 \mu \mathrm{m}$ in diameter.

Comparisons. Among the 76 Recent species of Stylaster (most listed by Cairns et al. 1999), 33 can be attributed to Stylaster group C as defined by Cairns (1983): those species having colonies with cyclosystems arranged in a sympodial pattern on branch edges. Stylaster griggi is a member of that group, species of which have a variety of coenosteal textures, including reticulate-granular and linear-imbricate. The reticulate-imbricate texture of $S$. griggi appears to be unique in the group. Stylaster griggi is most similar to $S$. cocosensis Cairns, 1991, both species having imbricate coenosteal texture, white coenosteum, and similarly shaped ampullae. Stylaster cocosensis, known only from off Cocos Island, is also known from the same bathymetric range (293-576 m). Stylaster griggi differs from that species in having a ring palisade structure, larger cyclosystems, more dactylopores per cyclosystem, lacking nematopores, and, as mentioned before, reticulate-imbricate coenosteal texture.

REMARKs. This species was alluded to by Cairns (1992:127) as "the first records of stylasterids from the Hawaiian Islands exclusive of Laysan" and as "several unpublished records [being] present in the NMNH collections from other Hawaiian islands."

Distribution. Known only from Brooks Banks and off Kaua'i; 322-583 m.

ETYMOLOGY. This species is named in honor of Richard W. Grigg, who did much of the pioneering work in the biology and resource management of Hawaiian deepwater precious corals (see Grigg 1994 and 1998 for a partial bibliography and autobiography). He was also on board when most of the specimens were collected. 
Stylaster infundibuliferus, Cairns, n. sp.

Figures $5 A-G, 6 A-B$

TYPE MATERIAL. Holotype (USNM 1021952): male colony, SEM stubs 11071108,1112 , Pisces $V-522,6-9,26^{\circ} 13.428^{\prime} \mathrm{N}$, $174^{\circ} 31.016^{\prime} W$ ("Bank 8," northwest of Lisianski Island), $521 \mathrm{~m}, 5$ October 2003. Paratypes: USNM 1021953, 1 male colony and 5 small branches, Pisces $V-522,6-11,26^{\circ}$ $13.428^{\prime} \mathrm{N}, 174^{\circ} 31.016^{\prime} \mathrm{W}, 521 \mathrm{~m}, 5$ October 2003; usNm 1021954, 2 small colonies, Pisces $V-533,6-2,25^{\circ} 52.041^{\prime} \mathrm{N}, 171^{\circ} 57.848^{\prime} \mathrm{W}$ (northwest of Laysan), $563 \mathrm{~m}, 19$ October 2003.

Description. Colonies uniplanar to slightly bushy, moderately branched, and relatively small, the largest corallum (the holotype) only $12.5 \mathrm{~mm}$ tall, $28.3 \mathrm{~mm}$ wide, and $3.6 \mathrm{~mm}$ in basal branch diameter. Branching sympodial, most cyclosystems directed obliquely toward branch tip and occurring on opposite branch edges in an alternating arrangement (Stylaster group C sensu Cairns 1983); branch anastomosis rare. Coenosteum white and pronouncedly linearimbricate in texture, the parallel coenosteal strips $60-85 \mu \mathrm{m}$ in width, bordered by slits about $11 \mu \mathrm{m}$ wide. Platelets composing strips continuous across each strip and highly corrugated, each platelet having up to 8 longitudinal ridges above and an equal number of grooves below, the lower grooves articulating with the ridges of the adjacent (distalward) lower platelet (Figure $5 G$ ). Polarity of platelets primarily distal, but reversals of polarity are common (Figure 5C,E). Coenosteum, including ampullae and encrusting base, homogeneously and densely covered with large conical nematopores, each measuring up to $0.10 \mathrm{~mm}$ in diameter and $55 \mu \mathrm{m}$ in height; the top of each nematopore bears a concave depression.

Cyclosystems elliptical to somewhat irregular in shape, up to $1.6 \mathrm{~mm}$ in greater diameter, and having $\mathrm{H}: \mathrm{W}$ ratios ranging from 1.0 to 1.5. Upper abaxial edge of cyclosystems highly exsert, whereas adaxial edge flush with coenosteum. Based on 20 cyclosystems, the range of dactylopores per cyclosystem is $12-$ 18 , average $14.45(\sigma=1.50)$, and mode 14 .
Gastropore tube consists of three regions (Figure 6B), the lowermost region cylindrical and straight (about $0.2 \mathrm{~mm}$ in diameter and $0.5 \mathrm{~mm}$ in height), containing the gastrostyle and a diffuse ring palisade, the elements of which are about $40 \mu \mathrm{m}$ in diameter. The intermediate region of the tube slightly enlarges to about $0.30 \mathrm{~mm}$ in diameter and is about $0.4 \mathrm{~mm}$ in height, above which the tube greatly enlarges as an inner gastropore shelf region, this infundibuliform upper region about $0.7 \mathrm{~mm}$ in height and up to 1.5 $\mathrm{mm}$ in width, including the dactylopores and pseudosepta. Upper region lined with linear-imbricate coenosteal strips often in a concentric arrangement around the gastropore but also longitudinally arranged proceeding through the adcauline diastemas and then continuous with the branch coenosteal strips. Gastrostyles elongate, slender, and ridged (up to $0.45 \mathrm{~mm}$ in height and 90-95 $\mu \mathrm{m}$ in diameter), having a $\mathrm{H}: W$ ratio of $4.5-$ 5.0. Sharp, slender spines, up to $42 \mu \mathrm{m}$ in length and $6 \mu \mathrm{m}$ in diameter, occur on gastrostyle ridges. Dactylotomes $80-85 \mu \mathrm{m}$ wide; pseudosepta $80-100 \mu \mathrm{m}$ wide. Usually 1 adcauline diastema present, 2 if the cyclosystem occurs in a branching axil. Dactylostyles absent.

Male ampullae prominent superficial hemispheres up to $0.55 \mathrm{~mm}$ in diameter, often clustered on branch faces. Ampullae somewhat irregular in shape due to each having 4-6 large nematopores that project from the covering coenosteum. Ampullae develop at a very early stage; 5 are present on a founder polyp (Pisces V-533, 6-2). Female ampullae unknown.

comparisons. Among the 33 Recent species belonging to Stylaster group C, 18 have linear-imbricate coenosteal texture, and of those, six have a gastropore shelf that is covered by coenosteal strips, as in S. infundibuliferus: S. flabelliformis (Lamarck, 1816); S. duchassaingi Pourtalès, 1867; S. bilobatus Hickson \& England, 1905; S. laevigatus Cairns, 1986; S. spatula Cairns, 1986; and S. cocosensis Cairns, 1991. Of those, S. infundibuliferus is most similar to $\mathrm{S}$. duchassaingi, a species known only from the northwestern Atlantic at 183-549 $\mathrm{m}$ (Cairns 1986). They are similar 

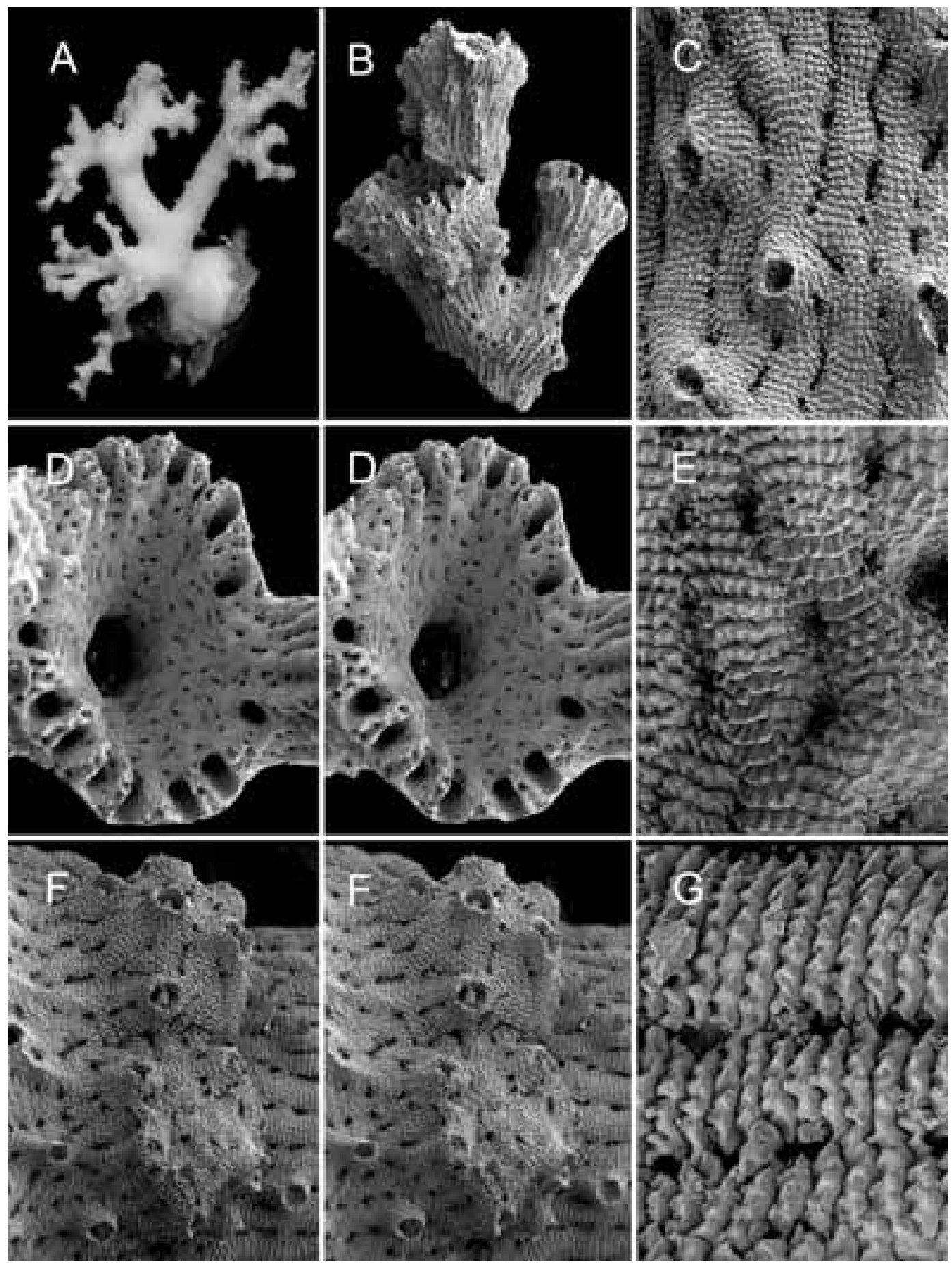

Figure 5. Stylaster infundibuliferus, holotype: $A$, holotype colony, $\times 2.0 ; B$, a terminal branch fragment, $\times 14 ; C$, branch coenosteum with several conical nematopores, $\times 91 ; D$, stereo pair of a cyclosystem with 15 dactylopores, $\times 35 ; E$, linear-imbricate coenosteum showing two examples of reversing polarity, $\times 190 ; F$, stereo pair of two superficial male ampullae, $\times 56$; $G$, corrugated coenosteal platelets, $\times 300$. 


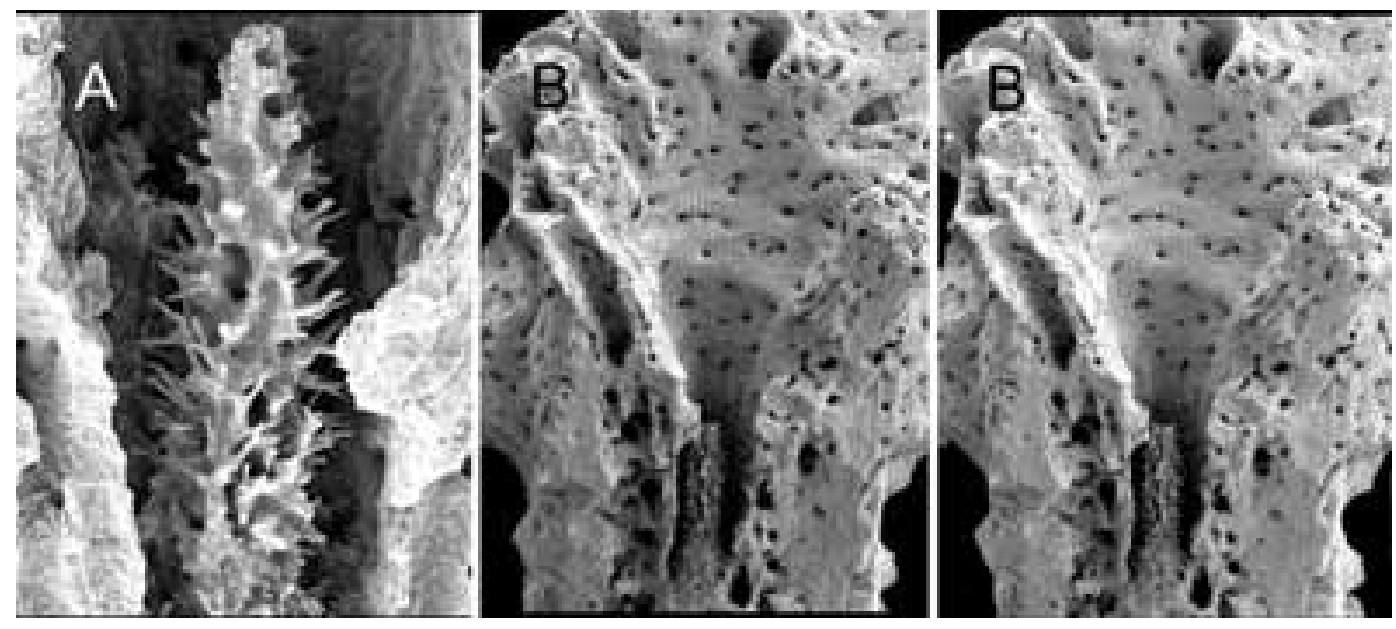

Figure 6. Stylaster infundibuliferus, holotype: $A$, gastrostyle, $\times 142 ; B$, stereo pair of longitudinal section of a cyclosystem and gastropore tube showing gastrostyle and internal coenosteal texture in upper chamber, $\times 37$.

in cyclosystem structure, number of dactylopores per cyclosystem, nematopore size and abundance, and coenosteal texture within the upper gastropore tube. Stylaster infundibuliferus differs in lacking dactylostyles; having larger cyclosystems; and having continuous, highly corrugated coenosteal plates.

Distribution. Known only from off Lisianski and Laysan Islands, Hawaiian Islands, $521-563 \mathrm{~m}$.

етумоlogy. The species name infundibuliferus (Latin: bearing infundibula) refers to the distinctive, funnel-shaped upper gastropore tubes. Nomenclaturally, it should not be confused with Stylaster scabiosus infundibulipora (Eguchi, 1968), a subspecies of a different species of Stylaster (group A) known from Sagami Bay, Japan.

\section{ACKNOWLEDGMENTS}

I am grateful to Amy Baco-Taylor, for inviting me to participate in the Pisces $V$ cruise and for permission to study the collected stylasterids. Her cruise was supported by NOAA-OE grant NA0OAR4600108. I am also grateful to Pisces submersible pilot Chuck Holloway and RCV pilots Dan Greeson and Mark Dewery for their assiduous efforts to obtain additional specimens of $D$. anceps.
Also, I thank Beatrice and Tom Burch, inveterate invertebrate collectors of Hawaiian fauna, for several of the specimens used in the study. Staff illustrator Molly Ryan drafted Figure 2.

\section{Literature Cited}

Boschma, H. 1959. Revision of the IndoPacific species of the genus Distichopora. Bijdr. Dierkd. 29:121-171, 16 pls.

. 1964. On variation in Stylaster sanguineus. Proc. K. Ned. Akad. Wet. Ser. C Biol. Med. Sci. 67 (4): 183-194, 4 figs.

Cairns, S. D. 1978. Distichopora (Haplomerismos) anceps, a new stylasterine coral (Coelenterata: Stylasterina) from deep water off the Hawaiian Islands. Micronesica 14 (1): 83-87, 6 figs.

1983. A generic revision of the Stylasterina (Coelenterata: Hydrozoa). Part 1. Description of the genera. Bull. Mar. Sci. 33 (2): 427-508, 28 pls.

. 1986. A revision of the Northwest Atlantic Stylasteridae (Coelenterata: Hydrozoa). Smithson. Contrib. Zool. 418:131 pp., 53 figs., 25 maps.

1991. Catalog of the type specimens of stony corals (Milleporidae, Stylasteridae, Scleractinia) in the National Museum 
of Natural History. Smithson. Contrib. Zool. 514:59 pp.

1992. Worldwide distribution of the Stylasteridae (Cnidaria: Hydrozoa). Sci. Mar. 56 (2-3): 125-130, 1 fig.

Cairns, S. D., and I. G. Macintyre. 1992. Phylogenetic implications of the calcium carbonate mineralogy in the Stylasteridae (Cnidaria: Hydrozoa). Palaios 7:96-107, 5 figs.

Cairns, S. D., and B. W. Hoeksema. 1998. Distichopora vervoorti, a new shallow-water stylasterid coral (Cnidaria: Hydrozoa: Stylasteridae) from Bali, Indonesia. Zool. Verh. (Leiden) 323:311-318, 17 figs.
Cairns, S. D., B. W. Hoeksema, and J. van der Land. 1999. Appendix: List of extant stony corals. Atoll Res. Bull. 459:13-46.

Grigg, R. W. 1994. History of the precious coral fishery in Hawaii. Precious Corals Octocoral Res. 3:1-18, 7 figs. 1998. Big surf deep dives and the islands: My life in the ocean. Editions Limited, Honolulu.

Lindner, A., S. D. Cairns, and H. M. Guzman. 2004. Distichopora robusta sp. nov., the first shallow-water stylasterid (Cnidaria: Hydrozoa: Stylasteridae) from the tropical eastern Pacific. J. Mar. Biol. Assoc. U. K. 84:1-5, 2 figs. 
